\title{
Gender Influences in the Labour Market: The Case of BRICS
}

\author{
Prof Pinky Lalthapersad-Pillay \\ University of South Africa,Department of Economics \\ Email:lalthp@unisa.ac.za
}

Doi:10.5901/mjss.2014.v5n10p146

\begin{abstract}
The aim of the article is to determine how women workers in the five BRICS countries fare with regard to key labour market indicators so as to gain an insight into the gender segregation of employment sectorally, industrially and firm-wise. Such indicators provide a measure of the extent of gender equality in these labour markets. The methodology entailed an analysis of published data from two different sources, namely, World Development Indicators and data from the World Economic Forum. The study showed that although the labour market outcomes for women workers are varied across the BRICS countries, there are some similarities. The majority of BRICS countries conform to the gender segregation of employment as depicted by a marked presence of women workers in services, a negligible proportion in industry and the majority of countries having just above $40 \%$ of women employed in the non-agricultural sector. India has a skewed proportion of women workers in agriculture, in self-employment, in vulnerable employment and in the informal sector. The proportion of female employers was generally low for all countries as well as their ability to accede to positions of leadership. Russia fared well with regard to the female participation in firm ownership but South Africa had the highest levels of both female unemployment and female youth unemployment. In terms of the gender gap between males and females in terms of economic participation and opportunity, Russia is closest to equality and is the most highly ranked (42 of 136 countries).
\end{abstract}

Keywords: BRICS, gender, labour markets, employment, female employees

\section{Introductory Remarks}

The association of the BRICS countries has grown into a formidable one that collectively account for $21 \%$ of the global GDP. These groups of countries have much influence internationally and regionally, as well as in sub-Saharan Africa. The aim of the article is to determine how women in these five countries fare with regard to key labour market indicators so gain an insight into the segregation of employment sectorally, industrially and firm-wise. Such indicators provide a measure of the extent of gender equality in these labour markets, and are valid in the context of evidence citing the growing importance of gender equality for countries in terms of their efficient utilization of human capital and for enhancing its economic growth. The literature on gender equality unequivocally also point to key role that gender equality plays in promoting economic development, the empowerment of women and competitiveness among countries. It has also been argued that countries that discriminate against women could be at a disadvantage as it could potentially lose out on the skills and expertise of women.

We look at the segregation of employment in these five countries from 2 angles, firstly, in terms of actual levels of women workers per labour market indicator. Secondly, we examine gender equality in terms of outcomes as measured by gender gaps, a measure that is independent of levels or inputs. We start with an overview of the BRICS association. This is followed by a discussion on the segregation of employment and why gender equality is being viewed as beneficial to a country's economic growth. Lastly, we analyse gender differentials across various labour market indicators. The study shows that although the labour market outcomes for women workers are varied across the BRICS countries, there are some similarities. The majority of BRICS countries conform to the gender segregation of employment as depicted by a marked presence of women workers in services, a negligible proportion in industry and the majority of countries having just above $40 \%$ of women employed in the non-agricultural sector. India has a skewed proportion of women workers in agriculture, in self-employment, in vulnerable employment and in the informal sector. The proportion of female employers was generally low for all countries as well as their ability to accede to positions of leadership. Russia fared well with regard to the female participation in firm ownership but South Africa had the highest levels of both female unemployment and female youth unemployment. In terms of the gender gap between males and females in terms of economic participation and opportunity, Russia is closest to equality and is the most highly ranked (42 of 136 countries). 


\section{Literature Review}

\subsection{An overview of the BRICS association}

BRICS is an acronym referring to a group of five countries that initially in 2009 comprised Brazil, India, China and Russia with South Africa joining in 2010. According to the World Banks classification of countries, South Africa, Brazil and China are deemed upper middle income countries, with Russia classified as a high income country and India as a lower middle income country (World Bank, 2012). The growth potential of the BRIC countries has been widely acknowledged and Goldman Sachs economists predicted that the BRIC economies (Brazil, Russia, India and China) would outperform that of the G7 countries (the richest countries) before the middle of the century (Glosny, 2010). Their formation is viewed as a mechanism to boost South-South co-operation and facilitate North-South co-operation (Arkhangelskaya, 2011). A distinguishing feature all BRICS countries is that they have been termed fast-developing, emerging economies or newly industrialized countries and whose economies are both huge and which exhibit robust levels of economic growth (BBVA, 2012). They all boast enormous political clout in their respective regions and in the international arena with all five countries being members of the G-20 group of countries. A crucial factor is that all BRICS countries hold important stocks of resources that can be offered to the global economy and which amounts to a positive spinoff for each individual country (Arkhangelskaya, 2011).

The statistics for this group for 2013 is impressive; namely, they comprise almost 3 billion people $(43 \%$ of the global population) and cover a geographic expanse of 39.7 million sq.m (which amounts to more than a quarter of the global land surface). Their joint nominal GDP amounts to US $\$ 16.039$ trillion, they collectively produce $21 \%$ of the world's production and their joint foreign reserves are estimated to be in the region of US $\$ 4$ trillion (IMF, 2013; Christian Science Monitor, 2011; Arkhangelskaya, 2011). Research shows that BRICS have become a formidable economic force globally, by broadening trade and the flow of finance with the rest of the world and in particular with sub-Saharan Africa. Their voluminous trade with sub-Saharan Africa in primary product commodities exports from sub-Saharan Africa has led to the business cycle in sub-Saharan Africa closely resembling that of the BRICS (Diallo et al. 2014). Together the BRICS countries constitute the largest trading partners of Africa and the largest new investors (Chun, 2013).

South Africa is the weakest of the BRICS countries economically and is not on par with the other BRICS countries given its subdued economic performance, especially its constrained production levels. South Africa's GDP is the lowest of all the BRICS countries and is a paltry $25 \%$ of Russia's output level. But geographically, economically and politically, South Africa occupies an important place in the African continent and is regarded as the gateway to the rest of the continent, wielding much political clout (Arkhangelskaya, 2011).

In its initial conception, economic policy co-ordination was not envisaged as a function of the BRIC association. The assumption was that they would stay clear of forming an economic bloc but subsequent processes has seen the association aiming to acquire more geopolitical muscle (Arkhangelskaya, 2011). The BRICS association has been criticized on a number of fronts ranging from the intentions of individual countries and their combined intentions against the US (Glosny, 2010). However, we do not touch of the criticisms levelled against BRICS in this article. The future scenario of BRICs could see it expanded include countries such as Indonesia, Turkey, Australia, Algeria and Mexico (Arkhangelskaya, 2011).

\subsection{Why gender matters in the labour market?}

Globally the proportion of women joining the labour market has been buoyed by a number of factors. such as economic development, higher education acquirements among women and falling fertility which have transformed female participation rates over the past 25 years. Rising educational acquirements among women have pushed them to enter the world of work. Research shows that higher educated women have higher participation rates than low educated women. Furthermore, differences in productivity and remuneration can be attributed to differences in education, in work experience and to discrimination in the labour market. Other factors such as a rise in economic opportunities for women (in manufacturing and services) spurred by trade liberalization and the growth of export-oriented sectors such as garment production and light manufacturing have led to a demand for female labour (World Bank, 2012). Economic development can generate jobs that are more suitable to women's work, for example, the expansion of clerical work in the US during 1930-1950 and in China and Mexico more recently with the demand for factory work and in India with the demand for service jobs due to outsourcing of call centers (Duflo, 2011). Initially the location of production to cheap export-promoting zones promoted female labour force participation and the feminization of employment in manufacturing, especially in developing countries. In the past 15 years the spread of ICTs (Information and Communication Technology) has 
expanded trade in services and promoted the growth of ICT sectors in developing countries. Lately ICT-related jobs concentrated in software, call centers and geographical information services have become big in Malaysia and India. Differences in economic opportunities lead to differences in time use. Women's preponderance in flexible jobs (especially part-time jobs and informal sector jobs) allows women to combine outside work with care. The Business Processing Outsourcing (BPO) industry in India has grown rapidly since 1990 and led to the formation of many new, well-paid opportunities for women, including a range of "back office" services such as call centers (data entry and management, claims processing, secretarial services). India's BPO sector grew by $30-40 \%$ average annual growth rates from 2000 to 2008. Call centers have a preference for women workers, and in one study of 2500 call centers in 17 countries it was found that on average, $69 \%$ of frontline call center workers were women. In India it is close to $45 \%$ which is still high compared to the sex ratio of employment in most other countries (Jensen, 2010). Economic development and the improvement in infrastructure, especially electricity, water, roads and transport, all of which are time-reducing, enhance women's work outside the home (World Bank, 2012).

Over the past twenty-five years, there have been huge increases in women joining the labour market, resulting in the gender participation gap being narrowed. The labour market situation of women is such that generally women are less prone to working; they are remunerated less than men even if they do similar work and are likely to experience poverty despite their working status (Duflo, 2011). Between 1980 and 2009, the global rate of female labour participation increased from $50.2 \%$ to $51.8 \%$ and that of males fell from 82.05 to $77.7 \%$. Moreover, the gender difference in labour force participation rates fell from 32 percentage points in 1980 to 26 percentage points in 2009 (World Bank, 2012). Women's labour market participation in East Africa and Latin America grew by 15\% between 1971 and 1995, a rate that exceeded that for men and the gender difference in wages was lowered (Duflo, 2011).

The World Bank (2012) adds that to obtain a more holistic picture of how men and women encounter the labour market, the issue of gender differences in the labour market should ideally not only be confined only to the breakdown of the composition of the labour market and labour force participation rates, but should be widened to analyse productivity and earnings differences. Although the past 25 years has yielded some progress with regard to women's labour force participation, deep gender differences with regard to productivity and remuneration across sectors and jobs continue to exist. This may actually discourage women from investing in human capital, harm their well-being and disempower women (World Bank, 2012).

The term "employment (or labour market) segregation by gender, refers to the differences in the kind of jobs women and men do" (World Bank, 2012:206). Employment segregation by gender boils down to the fact that there are men's jobs and women's jobs which are captured by fundamental differences between these jobs across sectors, industries, occupations, types of jobs or firm type. The term employment segregation by gender embodies these differences. The segregation of employment is a key feature of most labour markets and is evident in the type of jobs that women and men perform sectorally, industrially, occupationally and firm-wise. Women globally tend to be located in the main in low-productivity jobs and have a negligible presence in influential positions in the labour market. Women workers tend to be confined to a limited number of sectors, namely, they have a greater presence in the agricultural sector (globally for the period $2003-2008,37 \%$ of all employed women compared to $33 \%$ of all employed men) and in the service sector (globally for the period $2003-2008,47 \%$ of all women employed against $40 \%$ of all employed men) whilst their employment in manufacturing is low compared to men. Global figures for the period 2003-2008 also show that women comprised $40 \%$ of the global workforce, accounted for $58 \%$ of all unpaid workers; only $44 \%$ were in wage employment whilst $50 \%$ were located in the informal sector. These differences even extend to women entrepreneurs and certain salient features of female enterprise ownership is apparent, namely, that women dominate micro, small and medium enterprises, very few own large firms, most of female-headed enterprises are run from home and most of their activities are borne out of necessity with entrepreneurship viewed as the last resort (World Bank, 2012).

A further aspect of the gender segregation of employment is that the work that men and women undertake is typically divided across both industry and occupation. Globally, women tend to be predominantly employed (over 50\%) in communal services (public administration, education, health, other social services); among professionals (including teachers and nurses); clerical workers; sales and service workers. They also make up the bulk of employment (more than $40 \%$ ) of workers in retail and restaurant sectors and among agricultural workers. The segregation per industry is the similar. These gender differences in employment are apparent with women more prone than men to work in sectors, industries, occupations and jobs where labour productivity is lower which translate into a gender differential in productivity and wages. The skewed division of men and women across industries and occupations is liable for the differential in wages between these two groups of workers, even after taking into account factors such as individual characteristics of workers and their human capital acquirements and residential area. Gender differences due to occupation and sector of employment give rise to $10-50 \%$ of the observed wage differential in 33 middle income countries and 14 high income 
countries (World Bank, 2012).

Research attests that gender inequality in education and employment reduces economic growth. This relationship operates from a number of different angles. Firstly, gender gaps in employment restrict the existing talent reservoir from which employers can draw on and therefore reduces the expertise of the workforce. Secondly, it has also been suggested that gender inequality in employment can lower economic growth through a demographic impact, that is, gender inequality in employment would produce higher fertility which in turn would lower economic growth. Thirdly, gender gaps in employment would reduce international competitiveness and in turn economic growth, especially in the case of those countries that have a competitive advantage in export-oriented growth industries. Lastly, it has been found that women's employment and earnings benefit their bargaining power in the home, which in turn has positive spinoffs on savings, and promotes better investment in children's health and education which ultimately benefit economic growth (Klasen \& Lamanna, 2009).

Discrimination against women retards development. On the other hand, empowering women is essential as it allows women access to things such as health, education, labour market participation. It also imbues women with voice and political clout. Koffi Annan, the previous Secretary-General of the UN went as far as saying that the entire MDG process would falter if gender equality was not achieved (Duflo, 2012). Indeed, many of the eight MDG goals are underpinned by the attainment of gender equality even though achieving gender equality is a separate Goal on its own (MDG Goal 3).

\section{AlM of the Study}

The aim of the article is to determine how women workers in the five BRICS countries fare with regard to key labour market indicators so as to gain an insight into the gender segregation of employment sectorally, industrially and firm-wise.

\subsection{Research Methodology}

The methodology entailed an analysis of published data from two different sources, namely, World Development Indicators and data from the World Economic Forum.

\section{Results}

Table 1 gives estimates on the economically active population and the labour force participation rate for BRICS countries for the period 2012, except for Brazil. All the data and information for China refers to Hong Kong, SAR.

Table 1: Selected data on economically active population

\begin{tabular}{|c|c|c|c|}
\hline Economically active population $^{1}$ & Unit & Year & Value \\
\hline Brazil & & 2012 & $104,745,358$ \\
\hline China & & 2012 & $787,632,272$ \\
\hline India & & 2012 & $484,343,281$ \\
\hline Russia & & 2012 & $77,062,828$ \\
\hline South Africa & & 2012 & $18,687,019$ \\
\hline Economically active population (\% share) ${ }^{2}$ & $\%$ & & \\
\hline Brazil & $\%$ & 2011 & 68.6 \\
\hline China & $\%$ & 2012 & 56.6 \\
\hline India & $\%$ & 2011 & 53 \\
\hline Russia & $\%$ & 2012 & 53 \\
\hline South Africa & $\%$ & 2012 & 35.3 \\
\hline Female labour force participation rate ${ }^{1}$ & $\%$ & & \\
\hline Brazil & $\%$ & 2012 & 60 \\
\hline China & $\%$ & 2012 & 52 \\
\hline India & $\%$ & 2012 & 29 \\
\hline Russia & $\%$ & 2012 & 57 \\
\hline South Africa & $\%$ & 2012 & 44 \\
\hline
\end{tabular}

Source: ${ }^{1}$ World Development Indicators, World Bank, ${ }^{2}$ National Statistics Office. 2013. 
The economically active population of the labour force are persons who were either 'working' (or employed) or 'seeking or available for work' (or unemployed). It pertains to a specific reference period (National Statistics Office, 2013). China and India which are the most populous countries globally also have the largest share of the economically active population. This fact has important labour market implications globally, regionally and locally. In terms of the percentage share of the economically active population, South Africa trails behind the other four countries.

The labour force participation rate "is the proportion of the population ages 15 and older that is economically active: all people who supply labour for the production of goods and services during a specified period" (ILO, 2013). The female LFPR of China and Russia compare favourably with that of the US (50\% in 2012) and the UK ( $56 \%$ in 2012) while that of Brazil's exceeds that of both the US and the UK. India has the lowest female LFPR of the BRICS grouping and is partly due to factors restricting women from working outside the home.

In terms of the educational attainment of the female population, the proportion of the female population with at least secondary education (\% ages 25 and older) for the period 2006-2010 were as follows: Brazil (50.5\%)); China (68.7\%); India (26.6\%); Russia (93.5\%) and South Africa (68.9\%) (UNDP, 2013). Once again India lags behind at the bottom but South Africa is on par with China.

\subsection{Women's labour market status}

Table 2 shows selected data on different labour market indicators for women workers in BRICS countries covering the period 2009 to 2011.

Table 2: Selected data on women's labour market status in BRICS

\begin{tabular}{|c|c|c|c|}
\hline $\begin{array}{l}\text { Female employees in agriculture (\% of total employment in the non- } \\
\text { agricultural sector) }{ }^{1}\end{array}$ & Unit & Year & Value \\
\hline Brazil & $\%$ & 2011 & 11 \\
\hline India & $\%$ & 2012 & 60 \\
\hline Russia & $\%$ & 2009 & 7 \\
\hline South Africa & $\%$ & 2011 & 4 \\
\hline $\begin{array}{l}\text { Share of women employed in the non-agricultural sector ( } \% \text { of female } \\
\text { employment) } 1\end{array}$ & $\%$ & & \\
\hline Brazil & $\%$ & 2009 & 47 \\
\hline China & $\%$ & 2011 & 50 \\
\hline India & $\%$ & 2010 & 19 \\
\hline Russia & $\%$ & 2011 & 51 \\
\hline South Africa & $\%$ & 2011 & 45 \\
\hline Female employees per industry ( $\%$ of female employment $)^{1}$ & $\%$ & & \\
\hline Brazil & $\%$ & 2011 & 12 \\
\hline China & $\%$ & 2012 & 4 \\
\hline India & $\%$ & 2012 & 21 \\
\hline Russia & $\%$ & 2009 & 19 \\
\hline South Africa & $\%$ & 2011 & 13 \\
\hline Female employees in services (\% of female employment) ${ }^{1}$ & $\%$ & & \\
\hline Brazil & $\%$ & 2011 & 77 \\
\hline China & $\%$ & 2012 & 96 \\
\hline India & $\%$ & 2012 & 20 \\
\hline Russia & $\%$ & 2009 & 74 \\
\hline South Africa & $\%$ & 2011 & 68 \\
\hline Females in vulnerable employment (\% of female employment) ${ }^{1}$ & $\%$ & & \\
\hline Brazil & $\%$ & 2009 & 22 \\
\hline India & $\%$ & 2010 & 85 \\
\hline South Africa & $\%$ & 2011 & 11 \\
\hline Self-employed females ( $\%$ of female employment) ${ }^{1}$ & $\%$ & & \\
\hline Brazil & $\%$ & 2009 & 25.1 \\
\hline China & $\%$ & 2012 & 5.6 \\
\hline India & $\%$ & 2010 & 85.5 \\
\hline South Africa & $\%$ & 2011 & 12.9 \\
\hline
\end{tabular}




\begin{tabular}{|c|c|c|c|}
\hline Female employers ( $\%$ of female employment) ${ }^{1}$ & $\%$ & & \\
\hline Brazil & $\%$ & 2009 & 2.7 \\
\hline China & $\%$ & 2012 & 1.4 \\
\hline India & $\%$ & 2010 & 0.4 \\
\hline South Africa & $\%$ & 2011 & 2.8 \\
\hline Female unemployment (as a \% of female employment) ${ }^{1}$ & $\%$ & & \\
\hline Brazil & $\%$ & 2011 & 9.1 \\
\hline China & $\%$ & 2012 & 2.7 \\
\hline India & $\%$ & 2012 & 4.0 \\
\hline Russia & $\%$ & 2012 & 5.1 \\
\hline South Africa & $\%$ & 2012 & 27.7 \\
\hline Female long-term unemployment (\% of female employment) ${ }^{1}$ & $\%$ & & \\
\hline India & $\%$ & 2010 & 1.8 \\
\hline Russia & $\%$ & 2012 & 1.6 \\
\hline South Africa & $\%$ & 2012 & 9.0 \\
\hline Female youth unemployment (\% of female employment) ${ }^{1}$ & $\%$ & & \\
\hline Brazil & $\%$ & 2011 & 19.8 \\
\hline China & $\%$ & 2012 & 7.8 \\
\hline India & $\%$ & 2012 & 11.6 \\
\hline Russia & $\%$ & 2012 & 15.1 \\
\hline South Africa & $\%$ & 2012 & 56.9 \\
\hline \multicolumn{4}{|l|}{ Female part-time employment ( $\%$ of total female employment) ${ }^{2}$} \\
\hline Brazil & $\%$ & 2011 & 28 \\
\hline Russia & $\%$ & 2011 & 5 \\
\hline South Africa & $\%$ & 2011 & 11 \\
\hline Female workers in informal sector (\% of non-agricultural employees) ${ }^{2}$ & $\%$ & & \\
\hline \begin{tabular}{|l|l|} 
Brazil & \\
\end{tabular} & $\%$ & 2012 & 39 \\
\hline China & $\%$ & 2012 & 36 \\
\hline India & $\%$ & 2012 & 83 \\
\hline South Africa & $\%$ & 2012 & 37 \\
\hline Ability of women to rise to positions of enterprise leadership² & $\%$ & & \\
\hline Brazil & $\%$ & 2013 & 4 \\
\hline China & $\%$ & 2013 & 5 \\
\hline India & $\%$ & 2013 & 5 \\
\hline Russia & $\%$ & 2013 & 4 \\
\hline South Africa & $\%$ & 2103 & 5 \\
\hline Firms with female top managers ( $\%$ of firms) & $\%$ & & \\
\hline Brazil & $\%$ & 2013 & 18 \\
\hline Russia & $\%$ & 2013 & 20 \\
\hline Firms with female participation in ownership (\% of firms) ${ }^{2}$ & $\%$ & & \\
\hline Brazil & $\%$ & 2012 & 59 \\
\hline India & $\%$ & 2012 & 9 \\
\hline Russia & $\%$ & 2012 & 29 \\
\hline South Africa & $\%$ & 2012 & 23 \\
\hline
\end{tabular}

Source: ${ }^{1}$ World Development Indicators, World Bank; ${ }^{2}$ WEF, 2013

Employees are defined as those "who work for a public or private employer and receive remuneration in wages, salaries, commission, tips, piece rates, or pay in kind." (ILO, 2013). The agricultural sector refers to the economic sectors comprising hunting, forestry and fishing. India has the highest percentage of female employees in agriculture (60\%).

The share of women employed in the non-agricultural sector refers to the share of female workers employed in industry and services. In terms of the share of female employment in the non-agricultural sector, the figures for the UK were 47\% in 2011 and for the US 48\% in 2012. The other four countries, Brazil, China, South Africa and Russia compare favourably with the status quo in the UK and the US with figures exceeding 40\% but it was the lowest in India (19\%). Industry includes mining and quarrying (including oil production); manufacturing; construction and public utilities (electricity, gas and water). Less than $20 \%$ of females are employed in industry but it exceeds the levels for the UK ( $8 \%$ in 
2012) and the US (7\% in 2010). Services include wholesale and retail trade; restaurants and hotels; transport, storage, and communications; financing, insurance, real estate, and business; and community, social and personal services. The proportion of females employed in services in China are very close to that of the US (92\% in 2012) and the UK (91\% in 2012) but on the overall, the data for all countries except India conform to the pattern of a greater presence of women in the service sector. India in future is likely to follow the same trend given the greater employment of women workers in the ICT-related jobs such as call centers.

Vulnerable employment refers to unpaid family workers and own-account workers. The figure for females in vulnerable employment for the UK was $8 \%$ in 2012. India had the highest levels and is due to the overwhelming presence of women in agriculture. Self-employed workers are those workers who, working on their own account or with one or a few partners or in cooperative, hold the type of jobs defined as "self-employment jobs" (jobs where the remuneration is directly dependent upon the profits derived from the goods and services produced. Self-employed workers include three subcategories: employers, own-account workers, and members of producer' cooperatives (ILO, 2013). There is no data for Russia but India has the greatest proportion of self-employed females due to women's preponderance in the agricultural sector where they are likely to be owners of small farms. China on the other hand, has the lowest proportion of women in self-employment. The levels in Brazil and South Africa are close to that for the UK (9.7\% in 2012) and for the US (5.5\% in 2011). Employers refers to those workers who, working on their own account or with one or a few partners, hold the type of jobs defined as a "self-employment jobs" i.e. jobs where the remuneration is directly dependent upon the profits derived from the goods and services produced), and in this capacity, have engaged on a continuous basis, one or more persons to work for them as employee(s). The percentage of female employers was negligible for all countries but was highest in South Africa and virtually non-existent for India. Even in the, UK it amounted to only1.4\% in 2012.

A serious challenge facing most economies worldwide is that of unemployment. Unemployment refers to the share of the labour force that is without work but available for and seeking employment. It must be noted that definitions of unemployment differ by country and should therefore be examined with caution. Unemployment among females was very high in South Africa (27.7\%) compared to the rest of the BRIC countries and has to do with a host of structural rigidities and the legacy of apartheid that underlined the acquisition of education and skills. It was the lowest in China, followed by Russia and was under 10\% in both the US (7.9\% in 2012) and the UK (7.3\% in 2012). Long-term unemployment refers to the number of people with continuous periods of unemployment extending for a year or longer, expressed as a percentage of the total unemployed. Female long term unemployment was highest in South Africa (9.0\%) whilst India and Russia compared well with the UK (2.2\% in 2012) and the US (2.3\% in 2012). Youth unemployment refers to the share of the labour force ages $15-24$ without work but available for and seeking employment. Female youth unemployment was extremely high in South Africa (56.9\%) and below $20 \%$ in the rest of the BRICS countries. For the UK it was $17.9 \%$ in 2012 and for the US it was 14.7\% in 2012. South Africa is purported to have the third highest level of youth unemployment globally, with Greece and Spain occupying the top two spots (South African Press Association, 2014).

Regarding the proportion of females in part-time employment, it was quite substantial in Brazil and low in Russia. Part-time work is often undertaken with the aim of combining flexibility with outside work. Informal sector employment by women was extremely high in India and above $30 \%$ in the rest of the BRICS countries. All countries fared very poorly with regard to the ability of women to rise to positions of leadership in enterprises. Firms with female top managers were close to $20 \%$ in both Brazil and Russia. The proportion of female participation in ownership was high in Brazil and very low in India due to women's preponderance in agricultural employment.

One indicator of women's economic standing in society and in fact their empowerment is their financial independence. One measure that can be used to gauge it is the number of women that have an account in a formal financial institution. The figures are as follows: China (60\%); Brazil and South Africa (51\%); Russia (48\%) and India (26\%) (WEF, 2013). India a very small proportion of women had an account in a formal financial institution and is aligned to its employment profile of women workers.

\subsection{Gaps in gender equality}

The previous section looked at the actual levels of women' participation in the different facets of the labour market and the following section focuses only on gaps pertaining to certain areas. The Global Gender Gap Index put forth by the World Economic Forum (WEF) gauges gender-based gaps in access to resources rather than actual levels of available resources and opportunities in countries. In other words, the Index looks at the gap in outcomes between males and females across certain dimensions rather than inputs accorded or the levels therein. Another feature of the Index is that it ranks countries according to gender equality rather gender empowerment (WEF, 2013).

The Global Gender Index analyses the gap between men and women in four basic sub-indexes, namely, economic 
participation and opportunity; educational attainment; health and survival and political empowerment. The sub-index economic participation and opportunity is what matters to us. This sub-index focuses on the following three areas:

- the participation gap which is based on differences in labour force participation;

- the remuneration gap which is based on the ratio of estimated female-to-male earned income and the WEF opinion survey relating to wage equality for similar work; and

- the advancement gap which is based on the ratio of women to men among legislators, senior officials and managers, as well as the ratio of women to men among technical and professional workers (WEF, 2013).

One hundred and thirty-sex countries are covered and the value of the sub-indexes range from 1 (equality) and to 0 (inequality). In the economic participation and opportunity sub-index, BRICS standing is shown in Table 3 below.

Table 3: Economic participation and opportunity sub-index for BRICS

\begin{tabular}{|c|c|c|}
\hline Country & Rank & Score \\
\hline Russia & 42 & 0.7204 \\
\hline China & 62 & 0.6752 \\
\hline Brazil & 74 & 0.6561 \\
\hline South Africa & 78 & 0.6506 \\
\hline India & 124 & 0.4465 \\
\hline
\end{tabular}

Source: WEF, 2013.

The information in Table 3 refers to the gender gap between males and females. A score close to 1 signifies smaller gender gaps. Russia is well placed in the rankings (at 42) while India is placed $12^{\text {th }}$ from the bottom (ranked 124 out of 136 countries). The other three BRICS countries fall within the range of 60 to 80 . The UK is ranked 35 with a score of 0.7320 . The US is ranked within the top 10 (at number 6 ) with a score of 0.8185 . Norway ranks number 1 of all countries.

\subsection{Female-to-male-ratios}

A further breakdown of the 4 sub-categories that determine the economic participation and opportunity index is given in Table 4 below. However, this information gives the female-to-male ratio per sub-category. These values are not condensed to provide a equality measure but show cases of reverse gender gaps that exist if the ratio exceeds 1.000 (WEF, 2013).

Table 4: Female -to-male-ratios per sub-category

\begin{tabular}{|l|c|}
\hline Labour force participation & Female-to-male ratio \\
\hline Brazil & 0.76 \\
\hline China & 0.88 \\
\hline India & 0.36 \\
\hline Russia & 0.87 \\
\hline South Africa & 0.75 \\
\hline Perceived wage equality for similar work survey data & 0.54 \\
\hline Brazil & 0.66 \\
\hline China & 0.62 \\
\hline India & 0.63 \\
\hline Russia & 0.65 \\
\hline South Africa & \\
\hline Estimated earned income & 0.61 \\
\hline Brazil & 0.64 \\
\hline China & 0.27 \\
\hline India & 0.62 \\
\hline Russia & 0.52 \\
\hline South Africa & \\
\hline Legislators, senior officials and managers & 0.56 \\
\hline Brazil & \\
\hline
\end{tabular}




\begin{tabular}{|l|c|}
\hline China & 0.20 \\
\hline Russia & 0.63 \\
\hline South Africa & 0.43 \\
\hline Professional and technical workers & \\
\hline Brazil & 1.10 \\
\hline China & 1.08 \\
\hline Russia & 1.81 \\
\hline South Africa & 1.07 \\
\hline
\end{tabular}

Source: WEF, 2013.

Table 4 also displays gender gaps between males and females and do not reflect actual levels. For labour force participation, the female-to-male ratios exceed 0,70 for all countries except for India, implying a smaller gender gap. The opinion survey on wage equality for similar work is above 0.6 for all countries except Brazil, implying that the gender gap is not so that big. The female-to-male ratios for estimated earned income was most profound in India while the rest of countries had ratios exceeding 0.5 , implying they gender gap was still quite high. Only Brazil and Russia fared well with regard to the female-to-male ratio for legislators, senior officials and managers while India and China still have a long way to go. For the sub-category professional and technical workers, all exhibit reverse gender gaps implying that they contain a large amount of female workers.

\section{Conclusion}

The association of the BRICS countries has grown into a formidable one that collectively account for $21 \%$ of the global GDP. These groups of countries have much influence internationally and regionally, as well as in sub-Saharan Africa. The aim of the article was to determine how women workers in the five BRICS countries fare with regard to key labour market indicators so as to gain an insight into the gender segregation of employment sectorally, industrially and firm-wise. Such indicators provide a measure of the extent of gender equality in these labour markets, and are valid in the context of evidence citing the growing importance of gender equality for countries in terms of their efficient utilization of human capital and for enhancing its economic growth. The literature on gender equality unequivocally also point to key role that gender equality plays in promoting economic development, the empowerment of women and competitiveness among countries.

The labour market situation of women is such that generally women are less prone to working; they are remunerated less than men even if they do similar work and are likely to experience poverty despite their working status (Duflo, 2011). A country's competitiveness depends on the quality of its human resources, especially the human capital acquirements, skills levels and the productivity of its workforce. Women form an intrinsic part of this talent reservoir. Research shows that countries that achieve parity in education also exhibit narrower gaps in women's economic participation Thus, among other things, the human capital of women matters crucially to the national output. Therefore eradicating gender gap is the cornerstone not only of improving a country's competitiveness but has human rights and equity imperatives (WEF, 2013).

What are the policy measures that aid women's employment? Legislation aimed at gender-based discrimination, compliance with quotas or subsidies to female businesses all aid gender equality (WEF, 2013). Gender equality is determined by national policy imperatives in countries. In recent years, gender mainstreaming in different areas have become standard practice in most countries. In South Africa, the Constitution endorsed gender equality in all spheres and the Employment Equity Bill seeks, among other things to eliminate discrimination and to advance women from designated groups. The new Women Empowerment Gender Equality Bill adopted in 2014 specifies that at least half of all decisionmaking posts are held by women. Russia has also prioritised gender equality and its effect is evident in the number of women employed at senior management levels (Shevel, 2014). Policies such as parental leave and the support for child care also influence women's labour force participation (WEF, 2013).

\section{References}

Arkhangelskya, A.A. (2011). 'IBSA- BRICS: rivals or allies'. Paper presented at the International workshop on South-South Co=operation and the new forms of Southern Multilateralism; BRICS/IBSA-Africa relation: Turning threats to opportunity. Uppsula. 13-14 June 2011.

BBVA. (2012). BBVA Annual Report. Retrieved 10th March 2014. http://www.bbvaresearch.com/KETD/fbin/mult/120215 
Christian Science Monitor. (2011). Amid BRICS' rise and 'Arab Spring', a new global order forms. Retrieved 29th January 2013.http://www.csmonitor.com/World/Global-Issues/2011/1018

Diallo, O., Sampawende, J. \& Tapsoba, J. (2014). 'Rising BRICS and changes in sub-Saharan Africa's business cycle patterns,' IMF Working Paper: International Monetary Fund.

Duflo, E. (2011). 'Women's employment and economic development,' National Bureau of Economic Research. Retrieved 29th December 2013. http://www.nber.org/papers/w17702

Glosny, M.A. (2010). 'China and the BRICS: A real (but limited) partnership in a unipolar world,' Polity, 42.

ILO, (2013). Key indicators of the labour market. Retrieved $8^{\text {th }}$ March 2014. www.ilo.org/kilm

IMF, 2013. World Economic Outlook. Retrieved 20 February 2013. http://www.imf.org/external/pubs/ft/weo/ 2013/01/weodata/weorept.aspx

Jensen, R.T. (2010). 'Economic opportunities and gender differences in human capital: experimental evidence for India'. National Bureau of Economic Research. http://www. nber.org/paper/w/16021.

Klasen, S. \& Lamanna. F. 2009. 'The impact of gender inequality in education and employment on economic growth: new evidence for a panel of countries,' Feminist Economics, http://dx.doi.org/10.1080/13545700902893106. 23 July 2009.

National Statistics Office of the BRICS Group. BRICS Joint Statistical Publication 2013. Bricsforum. Retrieved 20 March 2014.http://www.bricsforum.org

Shevel, A. (2014). SA companies falling shy of gender quotas. Sunday Times, 9th March 2014.

South African Press Association. (2014). SA youth unemployment third worst in world, says Numsa. 17th March 2014.

UNDP. (2013). Human Development Report 2013: The rise of the South - Human progress in a diverse World. Retrieved 15th December 2013.http://hdr.undp.org

World Bank, (2012).World Development Report 2012: Gender Equality and Development. Washington DC: World Bank.

World Bank. World Development Indicators. Retrieved 9th March 2014. http://data.worldbank.org/topic

Zhun, C. 2013. 'A promising partnership between BRICS and Africa: A Chinese perspective,' The Chinese Monitor, Special edition. Centre for Chinese Studies, Stellenbosch University 